\title{
Romantik İlişsi Becerileri Psikoeğitim Programının Etkinliğinin Sınanması: Bir Pilot Çalışma
}

\section{Examining the Effectiveness of a Romantic Relationship Skills Psychoeducation Program: A Pilot Study}

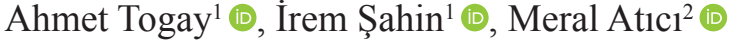

'Arş. Görv., ${ }^{2}$ Prof. Dr., Çukurova Üniversitesi, Eğitim Fakültesi, Rehberlik ve Psikolojik Danışma Anabilim Dalı, Adana, Türkiye

ORCID: A.T. 0000-0002-7611-5125;

i.Ş. 0000-0001-7146-0205;

M.A. 0000-0003-0675-4439

Sorumlu yazar/Corresponding author: Ahmet Togay,

Çukurova Üniversitesi, Eğitim Fakültesi, Rehberlik ve Psikolojik Danışma Anabilim Dalı, Adana, Türkiye

E-posta/E-mail: atogay@cu.edu.tr

Başvuru/Submitted: 05.11.2018 Revizyon Talebi/Revision Requested: 05.01.2019

Son Revizyon/Last Revision Received: 14.04.2019

Kabul/Accepted: 20.04 .2019

Online Yayın/Published Online: 24.06.2019

Atıf/Citation: Togay, A., Sahin, I., Atici, M. (2019). Romantik ilişki becerileri psikoeğitim programının etkinliğinin sınanması: Bir pilot çalışma. Psikoloji Çalışmaları - Studies in Psychology, 39(1): 121-149.

https://doi.org/10.26650/SP2018-0033
ÖZ

Genç yetişkinlik, romantik ilişkilerin ön planda olduğu bir gelişimsel dönemdir ve bu dönemde sağlıklı romantik ilişkiler kurma konusunda genç yetişkinler çeşitli problemler yaşayabilmektedir. Bu araştırmada, genç yetişkin bireylere yönelik geliştirilen romantik ilişki becerileri psikoeğitim programının etkinliğinin sınanması hedeflenmiştir. Psikoeğitim programının etkinliğinin sınanması nicel ve nitel yolla gerçekleştirilmeye çalışılmıştır. Araştırmada ön test-son test kontrol gruplu yarı deneysel desen kullanılmıştır. Psikoeğitim programının etkinliğini nicel olarak test etmek için karma desen iki yönlü ANOVA testi kullanılmıştır. Ayrıca programın uzun süreli etkinliğini nitel olarak sınamak için müdahale sonrasında katılımcılarla odak grup görüşmesi gerçekleştirilmiştir. Çalışma grubu, Akdeniz bölgesinde yer alan bir üniversitede öğrenim gören ve en az altı aydır devam eden bir romantik ilişkisi olan 24 (deney grubunda 12, kontrol grubunda 12) üniversite öğrencisinden oluşmaktadır. Psikoeğitim programının etkinliğini nicel olarak sınamak için katılımcıların ilişki doyumları incelenmiş ve bunun için ön test ve son test ölçümlerinde İlişki İstikrarı Ölçeği'nin ilişki doyumu alt ölçeği kullanılmıştır. Deney ve kontrol gruplarının tekrarlı ölçümlerinden elde edilen ilişki doyumu düzeylerine ilişskin toplam puanları arasında anlamlı bir fark olmadığı ancak gruplar içi ön test ve son test ilişki doyumu düzeylerine ilişkin puanlar arasında anlamlı bir fark olduğu belirlenmiştir. Ayrıca, farklı işlem gruplarında olmak ile tekrarlı ölçümler faktörlerinin ilişki doyumu üzerindeki ortak etkilerinin anlamlı olduğu belirlenmiştir. Buna göre deney grubundaki katılımcıların, kontrol grubunda olup bu eğitimi almayan katılımcılara göre ilişki doyumu düzeylerinde anlamlı bir artış olduğunu belirlenmiştir. Odak grup görüşmesinden elde edilen bulgulara göre, psikoeğitim programından sonra katılımcıların ilişki doyumlarındaki olumlu gelişimin devam ettiği görülmüştür. Ayrıca katılımcılar iletişim, ilişki inançları, hedefe ulaşma ve beklentiler gibi konularda kazandıkları bilgi, beceri ve farkındalıkların ilişkilerini olumlu yönde etkilediğini ifade etmişlerdir. Araştırma sonucunda elde edilen hem nicel hem de nitel bulgular psikoeğitim programının amacına ulaştığını göstermiştir.

Anahtar Kelimeler: Romantik ilişkiler, ilişki doyumu, psikoeğitim programı, pilot çalışma, genç yetişkinler 


\section{ABSTRACT}

The aim of this study was to test the effectiveness of a psychoeducation program of romantic relationship skills developed for young adults. The effectiveness of the psychoeducation program was tested using quantitative and qualitative methods. A pre-test post-test control group semi-experimental design was used in the study. Additionally, a focus group interview was conducted with the participants after the intervention to test the long-term effectiveness of the program. The study group consisted of 24 university students (12 in the experimental group and 12 in the control group) who were studying in a Mediterranean university and who had been in a romantic relationship for at least six months. In order to test the effectiveness of the psychoeducation program, the relationship satisfaction of the participants was examined and the relationship satisfaction subscale of the Relationship Stability Scale was used in the pre-test and post-test measurements. There was no significant difference between the total scores for relationship satisfaction levels obtained from the repeated measurements of the experimental and control groups. However, there was a significant difference between the pre-test and post-test relationship satisfaction levels. The interaction effects of being in different treatment groups and the repeated measurement factors on relationship satisfaction were significant. Accordingly, it was determined that the participants in the experimental group experienced a significant increase in relationship satisfaction levels compared to the participants who did not receive this training in the control group. According to the findings of the focus group interview, it was observed that the positive development of the participants' relationship satisfaction continued after the psychoeducation program. The participants stated that they saw a positive effect on their relationships thanks to the knowledge, skills and awareness they gained in areas such as communication, relationship beliefs, and expectations. The findings obtained in study showed that the psychoeducation program had achieved its aims.

Keywords: Romantic relationships, relationship satisfaction, psychoeducation program, pilot study, young adults

\section{EXTENDED ABSTRACT}

In terms of development, young adulthood is a period in which romantic relations are at the forefront. Research has shown that university students experience problems with developing healthy romantic relationships and that these are serious problems for their lives (Erkan, Özbay, Cihangir-Çankaya, \& Terzi, 2012; Gizir, 2005; Kılıç, 1995; Topkaya \& Meydan, 2013; Yazıcl, 2003). The aim of this study was to test the effectiveness of a psychoeducation program of romantic relationship skills developed for young adults.

\section{Method}

\section{Participants}

The study group consisted of 24 young adults (12 young adults in the experimental group, 12 young adults in the control group) who were studying at a university located in the Mediterranean region. The study included students who had been in a romantic relationship for at least six months. Participants who had a general symptom average score of 1 or more points were excluded from the study according to the scores obtained from the Brief Symptom Inventory (Derogatis, 1992; Şahin \& Durak, 1994). In addition, participants who had been subjected to physical violence by their partners, who had used physical violence against their partners, who lived together with their partners or had spent less than six months in a relationship were excluded from the study. 


\section{Measures}

The Brief Symptom Inventory (Derogatis, 1992; Şahin \& Durak, 1994) was applied to individuals to check if they suffered any psychopathology. The Relationship Satisfaction Scale subdimension of Relationship Stability Scale (Büyükşahin, Hasta, \& Hovardaoğlu, 2005; Rusbult, Martz, \& Agnew, 1998) was used to determine the relationship satisfaction levels of the participants in the experimental and control groups.

\section{The intervention program}

The Romantic Relationship Skills Psychoeducation Program consists of 8 sessions lasting 90 minutes each. The program consists of goal setting, self-recognition in romantic relationships, romantic relationship styles and stages, expectations and romantic beliefs, gender differences in romantic relationships, attachment and communication dimensions.

\section{Procedure}

A pre-test post-test control group semi-experimental design was used in the study. The psychoeducation program was applied to the experimental group and no intervention was applied to the control group. At the beginning of the experimental process, the independent samples t-test was used to assess whether there was a significant difference between the experimental and control groups in terms of relationship satisfaction. The two-factor mixed design ANOVA test was used to test the study's hypotheses.

\section{Results}

According to the findings of the study, there was no significant difference between the total scores of the relationship satisfaction levels obtained from the between-group test for the experimental and control groups, $F(1,19)=0.72, p>.05$. However, it was found that there was a significant difference between the scores of intra-group pre-test post-test relationship satisfaction levels, $F(1,19)=4.37, p<.05$. It was also found that participants in the experimental and control groups showed a significant difference in the pre-test and post-test measurements of the levels of relationship satisfaction after the psychoeducation program. Thus, the interaction effect of being in different treatment groups and repeated measurement factors on the relationship satisfaction was significant, $F(1,19)=35.06, p<$ .001. It was also determined that the common interaction of group (experiment-control) and repeated measurement (pre-test post-test) had a high influence $\left(\eta^{2}=.65\right)$ on the relationship satisfaction scores. Accordingly, the change observed in the repeated (pre- 
test post-test) measures of participants' level of relationship satisfaction was significantly different between the experimental and control groups.

A focus group interview was conducted to investigate the post-intervention effects of the psychoeducation program on the participants in the experimental group and the findings of this interview data showed that these positive developments continued after the psychoeducation program.

\section{Discussion}

According to our findings, the psychoeducation program had significant effects on relationship satisfaction levels of the individuals. The results obtained from this study concur with the findings of many previous examples of research, in which participants' relationship satisfaction and quality increased through various intervention programs (Antle, Sullivan, Dryden, Karam, \& Barbee, 2011; Carson, Carson, Gil, \& Baucom, 2004; Futris, Sutton, \& Richardson, 2013; Griffin \& Apostal, 1993; Larson, Vatter, Galbraith, Holman, \& Stahmann, 2007; Ledermann, Bodenmann, \& Cina, 2007; Long, Angera, Carter, Nakamoto, \& Kelso, 1999; Parish, 1992; Worthington et al., 1997).

There are some limitations to this study. Concerning the matter of gender, the number of male members in both groups was quite low and this is a concern in terms of adequacy of evaluation. The participants in the study were all students studying in an undergraduate program in the department of counseling and guidance at university. In future studies, working with participants from different undergraduate programs might provide richer evidence for the effectiveness of the program. It is also believed that conducting similar research with controls on the possible confounding variables which can affect relationship satisfaction might increase the significance of the results obtained. 
Genç yetişkinlik, gelişim görevleri açısından, romantik ilişkilerin ön planda olduğu bir dönemdir. $\mathrm{Bu}$ dönem, romantik ilişki arayışı içine giren genç erkek ve kadınların, duygusal olarak olgunlaşacakları ve yakınlık geliştirebilecekleri sağlıklı ilişki davranışları için ideal bir dönemdir (Erikson, 1968; Stover, 2008). Bundan dolayı, karşı cinsle yakın ilişkiler kurma ve eş seçme üniversite öğrencileri için önemli konular haline gelmektedir. Üniversite öğrencileriyle yapılan araştırmalar, karşı cinsle arkadaşlığın eş seçimini büyük oranda etkilediğini göstermiştir (Arnett, 2007; Braithwaite, Delevi ve Fincham, 2010; Collins ve van Dulmen, 2006; Weisskirch, 2017). Bu dönemde yaşanan romantik ilişkiler, bireylerin evliliklerinde ortaya çıkabilecek bazı sorunları yaşamalarını ve birbirlerini tanıyarak olumlu ve olumsuz yaşantılar geçirmelerini sağlamaktadır. Dolayısıyla, bu dönemin genç yetişkinler için karşı cinsle kurdukları romantik ilişkilerin özenle sürdürülmesi ve iyi değerlendirilmesi gereken bir dönem olduğu söylenebilir. Bununla birlikte, gençler bu dönemde romantik ilişkileriyle sıkıntı yaşayabilmektedirler Kılıç (1995) yaptığı araştırmada, üniversite öğrencilerinin dörtte birinin karşı cinsle ilişkilerde sorun yaşadığını ortaya koymuştur. Türk Üniversite Gençliği Araştırması’nda elde edilen bulgulara göre, üniversite öğrencilerinin \%10'u karşı cinsten arkadaşlarıyla ilişkilerinde sorun yaşamaktadır (Yazıcı, 2003). Ayrıca bu konuda yapılan diğer birçok araştırmada da benzer şekilde, üniversite öğrencilerinin sorun yaşadığı alanların başında karşı cinsle ilişkilerin geldiği görülmüştür (Erkan, Özbay, Cihangir-Çankaya ve Terzi, 2012; Gizir, 2005; Topkaya ve Meydan, 2013). Bu çalışmalar göz önüne alındığında, üniversite öğrencilerinin sağlıklı romantik ilişkiler geliştirmede sorun yaşadıkları ve bu sorunların onların yaşamı için ciddi bir problem alanı olduğu görülmektedir.

Sağlıklı ilişki; ilişkiyi yaşayan bireylere ilişkinin nasıl oluşacağını, devam edeceğini ve biteceğini öğrenmelerini sağlayan ve çatışma çözme için onlara firsat veren, öz yeterliliklerini ve öz saygılarını arttıran ilişki olarak ifade edilmektedir (Adler-Baeder, Kerpelman, Schramm, Higginbotham ve Paulk, 2007). Genç yetişkinlik döneminde sağlıklı romantik ilişkiler kurmayı başaramayan bireyler, duygusal olarak yalıtılmışlıkla karşı karşıya kalabilmektedirler. Ayrıca bu dönemde bireyler; partnerlerinin bireysel farklılıklarını görmeye açık olmayabilir, partnerlerden biri diğerini kendine benzetmeye çabalayabilir ve bunlar da hayal kırıklığı ve çatışmaya neden olabilir (Keitner, Heru ve Glick, 2010). Dolayısıyla, genç yetişkinlik çağındaki üniversite öğrencilerinin partnerleriyle ilişkilerinde, etkili iletişim kurma, yaşadıkları çatışmaları olumlu bir şekilde ele alabilme gibi konularda bilgi, farkındalık ve beceri kazanmalarının önemli olduğu söy- 
lenebilir. Bu bilgi, beceri ve farkındalıkları kazandırmanın yollarından biri ilişki geliştirme programlarıdır. Yurt içi ve yurt dışı alan yazında romantik ilişkilerle ilgili olarak geliştirilmiş ve etkinliği test edilmiş çok sayıda psikoeğitim programı bulunmaktadır. Örneğin yurt dışı alan yazında; Minnesota Çift İletişimi Programı (Nunnally, Miller ve Wackman, 1975), Evlilik Öncesi Eğitim ve Uygulama Dizisi (Bagarozzi, Bagarozzi, Anderson ve Pollane, 1984), Önleme ve İlişki Geliştirme Programı (Renick, Blumberg ve Markman, 1992), Empati Eğitimi Programı (Long ve ark., 1999), K1sa Bütünleştirilmiş Dinamik Grup Danışması (Cornish ve Benton, 2001), Farkındalık Temelli İlişki Geliştirme Programı (Carson ve ark., 2004), Bağlanma Odaklı Grup Müdahalesi (Kilman, Urbaniak ve Parnell, 2006), İlişki Değerlendirme (Larson ve ark., 2007), Aşk Yaşamı Programı (Hoffman, 2012), Evliliğinizi Başlamadan Önce Koruyun (Parrott ve Parrott, 1997) gibi farklı kuramsal yaklaşımları temel alan çok sayıda psikoeğitim programı bulunmaktadır. Yurtiçi alan yazında; Evlilik Öncesi Çift Eğitimi/PREP (Renick ve ark., 1992; Şen, 2009), Evlilik Öncesi İlişki Geliştirme Programı/SYMBIS (Parrott ve Parrott, 1997; Y1lmaz ve Kalkan, 2010), Evliliğe Hazırlık Programı/Marriage Preparation Program (Gottman ve Gottman, 2008; Haskan-Avc1, 2013), İlişki Geliştirme Programı/ Relationship Enhancement Program (Guerney, 2005; Yalçın ve Ersever, 2015) ve Sağlıklı İlişkiler Geliştirme Programı (Yalçıntaş-Sezgin, 2015) gibi psikoeğitim programlarının olduğu görülmektedir. Romantik ilişkilerle ilgili bu tür psikoeğitim programlarının geliştirilmesi ve uygulanması; bireylerin var olan ilişkilerinin daha sağlıklı hale gelmesini veya gelecekte yaşayacakları ilişkilerin daha sağlıklı olmasını sağlayabilir (Adler-Baeder ve ark., 2007). Hatta bu konuda son yıllarda bazı ülkelerde devlet kurumları genç yetişkin gruplara yönelik ilişki eğitimleri açarak bireylerin daha sağlıklı ilişkiler geliştirmelerini desteklemeye çalışmaktadır (Antle ve ark., 2011). Bu araştırmada da genç yetişkinlik çağındaki üniversite öğrencilerinin romantik ilişkilerini daha sağlıklı yürütebilmeleri için onları desteklemeyi amaçlayan bir psikoeğitim programının etkinliğinin nicel ve nitel yolla incelenmesi amaçlanmıştır.

$\mathrm{Bu}$ araştırma romantik ilişki becerilerine yönelik olarak geliştirilmiş olan psikoeğitim programının pilot çalışmasıdır. Bu çalışmada, oturumlarda belirlenen amaçlara ulaşmak için psikoeğitim programının nasıl uygulanacağını; programda yer alan yöntem ve tekniklerin hedeflenen davranışları kazandırmak için yeterli olup olmadığnı; oturumların amaç, hedef davranış, süre ve kullanılan araç gereç gibi boyutlar açısından amaca uygun ve etkili olup olmadığını; programın katılımcılar üzerindeki etkilerini belirleye- 
bilmek için kullanılacak olan ölçme yöntemlerinin yeterli olup olmadığını değerlendirerek programa nihai şeklini vermek için pilot uygulama yoluna gidilmiştir. Bu pilot çalışma süpervizyon altında yürütülen bir süreçtir, programın geliştirilmesi, uygulanması ve değerlendirilmesinde düzenli bir şekilde süpervizör görüşlerine başvurulmuş ve bu sayede pilot uygulamada karşılaşılan eksiklik, sorun ya da zorluklara karşı gerekli düzenlemeler yapılabilmiş ve bu sayede programın etkinliği arttırılmaya çalışılmıştır.

Psikolojik danışma yaklaşımlarının geliştirildikleri kültürün özelliklerini taşıdığı, bu durumun kuramlar için kültürel bazı sınırlılıkları beraberinde getirdiği ifade edilmektedir. Karaırmak (2008) psikolojik danışma yaklaşım ve uygulamalarının, kültürel faktörlerin bireylerin ruh sağlığı üzerindeki rolüne dikkat etmesi gerektiğini belirtmiştir. Yurt içinde romantik ilişki becerileriyle ilgili yapılan çalışmalar incelendiğinde, bu araştırmaların yurtdışında daha önce geliştirilmiş programların uyarlanarak Türk kültürüne uygunluğunun sınandığı çalışmalar olduğu görülmektedir. Bu araştırmalar kapsamında uyarlanan programlar şu şekildedir: Evlilik Öncesi Çift Eğitimi (Renick ve ark., 1992; Şen, 2009), Evlilik Öncesi İlişki Geliştirme Programı (Parrott ve Parrott, 1997; Yı1maz ve Kalkan, 2010), Evliliğge Hazırlık Programı (Gottman ve Gottman, 2008; Haskan-Avc1, 2013), İlişki Geliştirme Programı (Guerney, 2005; Yalçın ve Ersever, 2015). Sadece Yalçıntaş-Sezgin (2015) tarafından yapılan araştırmada Türk kültüründe geliştirilen, Sağlıklı İlişkiler Geliştirme Programı kullanılmıştır. Türkiye'de yapılan araştırmalarda etkinliği sınanan bu psikoeğitim programlarının farklı kültürlerde geliştirildiği göz önüne alındığında, bu durum bu programların Türk kültürüne uygunluğu konusunda önemli bir sınırlılık oluşturduğu söylenebilir. Bu konuda Kağıtçıbaşı (2008), sosyal bilimlerle ilgilenen uzmanların içinde bulundukları kültürü inceleyerek anlamaları ve o kültürle uyumlu uygulamalar geliştirmeleri gerektiğini vurgulamaktadır. Bu kapsamda bu araştırmada romantik ilişki becerileri konusunda Türk kültürüne uygun bir programın geliştirilerek pilot uygulamasının yapılması ve etkinliğinin sınanması amaçlanmıştır. Araştırmanın bu açıdan alan yazındaki romantik ilişkilerle ilgili uygulamadaki önemli bir boşluğu dolduracağı düşünülmektedir.

Romantik ilişkilerle ilgili geliştirilen programlar, bireylerin yeni beceriler öğrenerek davranışlarını değiştirmelerine ve romantik ilişkilerini geliştirmelerine yardım etmektedir (Shollenberger, 2001). Bu konuda geliştirilen psikoeğitim programlarının temel amacı da bireylerin daha fazla doyum sağladıkları bir ilişki geliştirebilmeleri için partnerlerin arasındaki ilişkinin geliştirilmesi, güçlendirilmesi ve korunmasıdır. Bireylerin 
yaşadıkları problemleri yapıcı bir şekilde ele alıp çözebilmelerinin ve aralarındaki ilişkiyi güçlendirmelerinin ilişkiden aldıkları doyumu artıracağı söylenebilir. Romantik ilişkilerinden doyum alan genç yetişkin bireylerin, yaşamlarının diğer alanlarının da bundan olumlu etkileneceği ve iyi oluşlarının artacağı düşünülmektedir. Özetle bu araştırmada, 'Romantik İlişki Becerileri Psikoeğitim Programı (RİBPP), romantik ilişkisi olan bireylerin ilişki doyumu düzeyleri üzerinde anlamlı bir etkiye sahip midir?’ sorusuna cevap aranmıştır. Genç yetişkin bireylere yönelik olarak geliştirilen RİBPP'nin etkinliğini test etmek amacıyla gerçekleştirilen bu araştırma, ön test-son test kontrol gruplu yarı deneysel bir araştırmadır. RİBPP araştırmanın bağımsız değişkeni, ilişki doyumu ise bağımlı değişkenidir. Deney grubuna RİBPP uygulanmış; kontrol grubuna ise herhangi bir müdahalede bulunulmamıştır. Bu amaçla aşağıdaki hipotez test edilmiştir:

"Katılımcıların ilişki doyumu puanlarına ilişkin tekrarlı (ön test-son test) ölçümlerinde gözlenen değişim, deney ve kontrol grupları arasında anlamlı bir fark göstermektedir."

Ayrıca RİBPP'nin etkinliğini sınamak, programın katılımcılar üzerindeki müdahale sonrası etkilerini izlemek ve söz konusu psikoeğitim programına ilişkin katılımcıların görüşlerini almak amacıyla nitel veri toplama yöntemlerinden odak grup görüşmesi yoluyla katılımcıların görüşleri alınmıştır. Bu amaçla araştırmacılar tarafından yarı yapılandırılmış odak grup görüşme formu hazırlanmıştır. Psikoeğitim programına katılan deney grubundaki katılımcılarla odak grup görüşmesi gerçekleştirilmiş ve elde edilen veriler nitel veri analizi yöntemlerinden içerik analizi yoluyla analiz edilmiştir.

\section{YÖNTEM}

\section{Katılımcılar}

Araştırmaya, Akdeniz bölgesinde bulunan bir üniversitenin psikolojik danışma ve rehberlik lisans programının 1, 2 ve 3. sınıflarında okuyan öğrencilerden en az 6 aydır devam eden romantik ilişkisi olan genç yetişkinler dahil edilmiştir. Gruba üye seçiminde grup sürecini olumsuz şekilde etkilemeyecek ve grup sürecinde kendi iyilik hali zarar görmeyecek kişilerin gruba seçilmesine özen gösterilmesi gerektiği ifade edilmektedir (Naar, 1993). Yalom (1995) grupla psikolojik danışmanın intihara eğilimli, aşırı parçalanmış ya da akut psikotik, sosyopatik, aşırı krizler yaşayan, paranoid ya da aşırı bencil kişiler için iyileştirici olmadığını belirtmiştir. Ayrıca Chen ve Rybak (2004), depresyon yaşayan, paranoya veya narsistik kişilik bozukluğu gibi patolojilere sahip bireylerin 
grup çalışmalarından yararlanma olasılığının düşük olduğunu ifade etmiştir. Bu araştırmada da araştırmaya dahil edilecek olan katılımcıların herhangi bir patolojiye sahip olup olmadıklarını belirlemek için Kısa Semptom Envanteri (KSE; Derogatis, 1992; Şahin ve Durak, 1994) kullanılmıştır. Normal örneklemlerde olduğu gibi, çeşitli psikopatolojik gruplarda ortaya çıkabilecek çeşitli semptomları belirlemek amacıyla kullanılan $\mathrm{KSE}$, çok boyutlu bir semptom tarama envanteridir. Envanterde genel semptom ortalaması puanının 0 ile 0.5 arasında olması psikopatolojinin olmadığına, 0.5- 1 orta derecede bir sorunun varlığına, 1 puan ve üstü ise psikopatolojinin varlığına işaret etmektedir (Şahin ve Durak, 1994). Buna göre, KSE genel semptom puanı 1 puan ve üstü olması bireyde psikopatolojinin varlığına işaret ettiği için, bu puana sahip bireyler çalışma grubuna dahil edilmemiştir. Alan yazın incelendiğinde romantik ilişkilerinde fiziksel şiddet yaşantısı olan bireylerin romantik ilişki becerileri programlara katılmalarının grup yapıs1 açısından riskli olduğu ve bu bireyler için özel programların daha uygun olduğu ifade edilmektedir (Markman, Stanley, Blumberg, Jenkins ve Whiteley, 2003; Monarch, Hartman, Whitton ve Markman, 2002). Buna göre araştırmada Kişisel Bilgi Formu'na verdikleri cevaplara göre partnerinin fiziksel şiddetine maruz kalan veya partnerine fiziksel şiddet uygulayan bireyler de çalışma grubunun dişında tutulmuştur.

Psikoeğitim çalışması ile ilgili yapılan duyurular neticesinde araştırmaya katılmak için toplam 30 kişi başvurmuştur. Bu kişilerin Kişisel Bilgi Formu’na verdikleri cevaplara ve KSE'den aldıkları puanlara göre; partnerinin fiziksel şiddetine maruz kalan aynı zamanda da genel semptom ortalaması puanı 1 puan ve üstü olan 1 kişi; partneriyle birlikte yaşayan 1 kişi, ilişki süresi 6 aydan daha az olan 1 kişi ve KSE genel semptom ortalaması puanı 1 puan ve üstü olan 3 kişi olmak üzere toplam 6 kişi araştırmaya dahil edilmemiştir. Çalışma grubu 1, 2 veya 3. sınıfta okuyan, yaşları 18-24 arasında değişen 24 katılımcıdan oluşmaktadır. Deney ve kontrol grubunda yer alan katılımcılara ilişkin diğer bilgiler Tablo 1'de sunulmuştur.

Tablo 1. Deney ve Kontrol Grubunda Yer Alan Katılımcıların Demografik Bilgileri

\begin{tabular}{llcccccc}
\hline \multirow{2}{*}{ Demografik Bilgiler } & \multicolumn{2}{c}{ Deney Grubu } & \multicolumn{2}{c}{ Kontrol Grubu } & \multicolumn{2}{c}{ Toplam } \\
\cline { 3 - 7 } & & $\boldsymbol{N}$ & $\boldsymbol{\%}$ & $\boldsymbol{N}$ & $\boldsymbol{\%}$ & $\boldsymbol{N}$ & $\boldsymbol{\%}$ \\
\hline Cinsiyet & Kadın & 9 & 75 & 10 & 83.33 & 19 & 79.17 \\
& Erkek & 3 & 25 & 2 & 16.67 & 5 & 20.83 \\
\multirow{2}{*}{ İlişki süresi } & 6 ay-1 yıl & 5 & 41.67 & 2 & 16.67 & 7 & 29.17 \\
& 1 yıldan fazla-3 yıldan az & 4 & 33.33 & 5 & 41.67 & 9 & 37.5 \\
& 3 yil ve üstü & 3 & 25 & 5 & 41.67 & 8 & 33.33 \\
\hline
\end{tabular}


Psikoeğitim programı yapısı gereği, ilişki doyumu düzeyi ortalama olan bireylerin ilişki doyumu düzeylerini yükseltmeye yönelik olarak tasarlanmıştır, bu nedenle ilişki doyumu düzeyi yüksek ve düşük olanlar dahil edilmemiştir. Bunu sağlayabilmek için İlişki İstikrarı Ölçeği'nin (Büyükşahin, Hasta ve Hovardaoğlu, 2005; Büyükşahin ve Taluy, 2008; Rusbult, Martz ve Agnew, 1998) ilişki doyumu alt boyutundan aldıkları puanlara göre ortalama ile ortalamanın 1 standart sapma arasında ve ortalama ile ortalamanın 1 standart sapma üstündeki aralıkta bulunan katılımcılar belirlenmiştir. Ayrıca, bu araştırmaya ilişki doyumu açısından ortalama puan alanlar bireyler alınarak araştırmanın iç geçerliği için tehdit olabilecek regresyonun önlenmesi amaçlanmıştır. Araştırmanın katılımcıları seçilirken, bazı katılımcıların bazı değişkenlerde uç değerler üretebilme olasılığı vardır ve ön testten düşük puan alan katılımcıların son testten yüksek puan alması ve ön testten yüksek puan alanların son testten düşük puan alması nedeniyle puanlardaki değişiklikler araştırmanın iç geçerliği için bir tehdittir (Heppner, Wampold ve Kivlighan, 1999). Bundan dolayı ilişki doyumu yüksek ve düşük olan katılımcılar araştırmaya dahil edilmemiştir. Bu kişiler deney ve kontrol gruplarına rastlantısal bir şekilde atanmıştır. Deney ve kontrol grubu 12 'şer kişiden oluşturulmuştur. Katılımcıların deney ve kontrol gruplarına atamaları yapıldıktan sonra, deney grubunda yer alan 7 katılımcının ilişki doyumu alt boyutundan aldıkları puanlara göre ortalama ile ortalamanın 1 standart sapma arasında, 5 katılımcının ise ortalama ile ortalamanın 1 standart sapma üstündeki aralıkta olduğu; kontrol grubunda ise; 4 katılımcının ilişki doyumu alt boyutundan aldıkları puanlara göre ortalama ile ortalamanın 1 standart sapma arasında, 8 katılımcının ise ortalama ile ortalamanın 1 standart sapma üstündeki aralıkta olduğu görülmüştür. Müdahalenin başlangıcında ilişki doyumu açısından deney ve kontrol grubu arasında anlamlı bir fark olup olmadığg bağımsız örneklemler $t$-testi ile incelenmiştir. İlişki doyumuna ilişkin ölçümlerin dağılımının deney ve kontrol grubunda normal dağılıp dağılmadığını saptamak için Shapiro-Wilks istatistiği kullanılmıştır. Buna göre Shapiro-Wilk istatistiğinin her iki grupta da anlamlı olmadığı dolayısıyla normalliğin sağlandığı görülmüştür. Ayrıca, varyansların homojenliği Levene $F$ testi ile incelenmiş ve varyansların homojenliği koşulunun karşılandığı görülmüştür. Buna ilişkin bulgular Tablo 2'de sunulmuştur.

Tablo 2. Psikoeğitim Programı Öncesinde Deney ve Kontrol Gruplarının İlişki Doyumu Puanlarının $t$-Testi Sonuçları

\begin{tabular}{lcccccc}
\hline Gruplar & $\boldsymbol{N}$ & $\boldsymbol{O r t .}$ & $\boldsymbol{S S}$ & $\boldsymbol{s . d}$. & $\boldsymbol{t}$ & $\boldsymbol{p}$ \\
\hline Deney & 12 & 41.92 & 2.27 & 22 & 1.65 & .11 \\
Kontrol & 12 & 44.17 & 6.75 & & & \\
\hline
\end{tabular}


Tablo 2'de görüldüğü gibi, bireylerin ön test ilişki doyumu puanlarının bulundukları gruba göre (deney ve kontrol) anlamlı bir fark göstermediği belirlenmiştir, $t(22)=1.65, p>.05$.

\section{Veri Toplama Araçları}

Kısa Semptom Envanteri (KSE). Bu envanter 90 maddeden oluşan Semptom Belirleme Listesi'nin (SCL-90, Derogatis, Rickels ve Rock, 1976) kısaltılmış formudur. Derogatis (1992) tarafından geliştirilmiştir. Normal örneklemlerde olduğu gibi, farklı psikopatolojik gruplarda ortaya çıkabilecek çeşitli semptomları belirlemek amacıyla kullanılan çok boyutlu bir semptom tarama envanteridir. Envanterin dokuz alt ölçeği için elde edilen Cronbach alfa iç tutarlılık katsayıları .71 ile .85 arasında değişmektedir. Ayrıca, 9 alt ölçek için hesaplanan test-tekrar test güvenirlik katsayısı değerlerinin .68 ile .91 arasında değiştiği saptanmıştır; 3 global rahatsızlık ölçeğinde ise bu katsayıların .80 ile .97 arasında değiştiği görülmüştür. Orijinal formun geçerlik çalışmaları kapsamında envanterin alt ölçekleri ile MMPI klinik ölçekleri ve MMPI'dan üretilen İçerik Ölçekleri ve Küme Ölçekleri arasındaki korelasyonların .30’un üzerinde olduğu ve bu korelasyonların KSE'nin uzun formu olan SCL-90'dan elde edilen korelasyonlarla, bazı alt ölçeklerde tümüyle özdeş, diğerlerinde ise çok yakın olduğu bulunmuştur. Envanterin orijinal formunun yapı geçerliği faktör analizi yoluyla incelenmiştir. Temel bileşenler yöntemi ve Varimax döndürmesine göre yapılan analizler sonucunda varyansin \%44'ünü açıklayabilen 9 faktör olduğu tespit edilmiştir (Derogatis, 1992).

Türkçeye Şahin ve Durak (1994) tarafindan uyarlanmıştır. Envanterin Türkçe formunda, envanterin tümünden elde edilen (belirti toplamı) Cronbach alfa iç tutarlılık katsayısının .95 olduğu, 9 alt boyutun Cronbach alfa iç tutarlılık katsayılarının .64 ile .84 arasında değiştiği saptanmıştır. KSE’nin 9 alt ölçeği ve 3 indeks puanının Beck Depresyon Envanteri ile korelasyonlarının $.34(p<.001)$ ile $.70(p<.001)$ arasında değiştiği belirlenmiştir (Şahin ve Durak, 1994). Envanter, beşli Likert tipinde ( $0=H i c ̧, 4=$ Çok fazla) toplam 53 maddeden oluşmaktadır. KSE, bu araştırmada deney ve kontrol grubunda yer alacak katılımcıların herhangi bir psikopatolojiye sahip olup olmadıklarını belirlemek için kullanılmıştır.

İlişki İstikrarı Ölçeği (İïÖ). İİÖ, 4 alt boyuttan (ilişki doyumu, ilişki yatırımı, seçeneklerin niteliğini değerlendirme, bağlılık) ve toplam 30 maddeden oluşmaktadır (Rusbult ve ark., 1998). Ölçeğin geçerlik ve güvenirliğini belirlemek amaciyla birbirini takip eden üç farklı çalışma yapılmıştır. Varimax eksen döndürme yöntemine dayalı faktör 
analizi sonucunda, ölçeğin 3 faktörlü bir yapıya sahip olduğu ve ölçek maddelerinin ölçmeyi amaçladığı faktörlerin altında toplandığı belirlenmiştir. Orijinal formda, alt ölçeklerin Cronbach alfa iç tutarlık katsayısı değerlerinin ilişki doyumu için .92 ile .95, ilişki yatırımı için .82 ile .84 ve seçeneklerin niteliğini değerlendirme için .82 ile .88 arasında değiştiği saptanmıştır.

Ölçek, Türkçe’ye Büyükşahin ve arkadaşları (2005) tarafından uyarlanmıştır. Bu çalışmada ölçek, orijinalinde olduğu gibi 3 alt boyuttan oluşmaktadır. Büyükşahin ve Taluy (2008) tarafından yapılan araştırmada ölçek tekrar gözden geçirilmiş ve bağlılık boyutu eklenmiştir. İIOO’nün Türkçe formunda alt ölçeklerinin güvenirliği için Cronbach alfa iç tutarlılık katsayısı ve iki yarım test güvenirliği incelenmiştir. Alt ölçeklerin Cronbach alfa katsayıları ilişki doyumu alt ölçeği için .90, seçeneklerin niteliğini değerlendirme alt ölçeği için .84, ilişki yatırımı alt ölçeği için ise .84 olarak belirlenmiştir. Alt ölçeklerin iki yarım test güvenirlik değerleri ise sırasıyla .84, .71, ve .78 olarak saptanmıştır (Büyükşahin ve ark., 2005). Bu araştırmada katılımcıların ilişki doyumu düzeylerini belirleyebilmek için ölçeğin ilişki doyumu alt boyutu kullanılmıştır.

Odak Grup Görüşme Formu. RİBPP'nin etkinliğini sınamak; söz konusu psikoeğitim programına ilişkin katılımcıların görüşlerini almak amacıyla araştırmacılar tarafından yarı yapılandırılmış odak grup görüşme formu hazırlanmıştır. Formda açımlayıcı sonda soruları da içeren toplam 7 açık uçlu soru bulunmaktadır. Odak grup görüşmesinde bu açık uçlu sorular yoluyla;

- katılımcıların psikoeğitim programından sonraki romantik ilişki doyumlarının nasıl olduğu,

- psikoeğitim programı süresince kazandıkları farkındalık, bilgi ve becerilerin programdan sonra ilişkilerine yansımaları/etkileri,

- romantik ilişkiden aldıkları doyumu arttırmak için programdan sonra neler yaptıkları,

- programa katılmış olmanın onlar için anlamı,

- grup yaşantısına başlarken hedefledikleri amaçlara hangi düzeyde ulaştıklarına ilişkin düşünce ve görüşlerinin alınması amaçlanmıştır.

\section{İşlem}

RİBPP, yurt içi ve yurt dışı alan yazındaki romantik ilişkilerle ilgili kuramsal açıklamalar, daha önce yapılmış benzer araştırmalar ve geliştirilmiş olan psikoeğitim prog- 
ramları incelenerek birinci araştırmacı tarafından hazırlanmıştır. Program, romantik ilişkiler ve psikoeğitim programı hazırlama konularında bilgi, beceri ve deneyimi olan bir uzmanın süpervizyonuyla (bu araştırmanın üçüncü yazarı) geliştirilmiştir. Program geliştirilirken ve uygulama sürecinde ise oturumlar arasında, süpervizörden grup oturumlarına ilişkin düzenli süpervizyon alınmıştır. Süpervizyon sürecinde alınan geribildirimler dikkate alınarak 8 oturum şeklinde planlanan program, romantik ilişkiler konusunda çeşitli konularda bilgi, farkındalık ve beceriler kazandıracak şekilde yapılandırılmıştır.

Programdaki amaçlar, etkinlik ve müdahaleler tasarlanırken üçgen aşk yaklaşımı, bilişsel davranışçı yaklaşım, bağlanma kuramı ve iletişimde farkındalık modeli/Johari Penceresi gibi model ve yaklaşımlar temel alınmıştır. Programda sırasıyla; amaç belirleme, romantik ilişkilerde kendini tanıma, romantik ilişki tarzları ve evreleri, beklentiler ve romantik ilişkiye ilişkin inançlar, cinsiyet farklılıkları, bağlanma ve iletişim boyutları bulunmaktadır. Psikoeğitim programının geliştirilmesi sürecinde, üçgen aşk kuramı (Sternberg, 1986) temel alınarak katılımcıların aşka ilişkin tanımlamalarının, kendileri için aşkın üç önemli özelliğinin ortaya koyulması ve bununla ilgili duygu ve düşüncelerini paylaşmaları amaçlanmıştır. Bununla birlikte üçgen aşk kuramının açıklamaları doğrultusunda grup üyelerinin kendi romantik ilişkilerinin hangi aşk türüyle (aşksız aşk, sevgi, delicesine aşk, boş aşk, romantik aşk, arkadaşça aşk, aptalca aşk, kusursuz aşk) benzerlik gösterdiğini değerlendirmeleri amaçlanmıştır (Acker ve Davis, 1992; Aron ve Westbay, 1996; Falconi ve Mullet, 2003; Fehr, 1986, 1993; Fehr ve Russell, 1991; Marston, Hecht, Manke, McDaniel ve Reeder, 1998; Sternberg, 1986). Ayrıca grup üyelerinin romantik ilişkinin evreleri, bu evrelerin özelliklerini ve kendi romantik ilişkilerinin içinde bulunduğu evreyi fark edebilmeleri için Campbell (1980) tarafindan geliştirilmiş olan beş evreli model temel alınmıştır (Bader ve Pearson, 1983). Grup üyelerinin romantik ilişkilerde kendi özelliklerini tanımaları, kendi algılarıyla partnerlerinin algılarını karşılaştırarak ilişkilerindeki açık, gizli, kör ve bilinmeyen alanlarını fark edebilmeleri ve ilişkideki benliklerine ilişkin farkındalıklarını arttırabilmeleri için iletişimde farkındalık modelinden (Johari penceresi) yararlanılmıştır (Gaw, 1976; Luft ve Ingham, 1961; Pronin, Lin ve Ross, 2002; South, 2007; Vazire ve Mehl, 2008). Kat1lımciların romantik ilişki ve partnerlerine ilişkin çeşitli alanlara ilişkin (birlikte zaman geçirme, arkadaşlık ve karşı cinsle ilişkiler, romantizm, özel günler, iletişim ve duyguları paylaşma, sadakat) beklenti ve inançlarını, bunların akılcı ve gerçekçi olup olmadığını, bu beklenti ve inançlarının romantik ilişkileri üzerindeki etkilerini fark edebilmeleri ve ro- 
mantik ilişki ve partnere ilişkin akılcı ve gerçekçi beklenti ve inançlar geliştirebilmelerini sağlamak amacıyla bilişsel davranışçı yaklaşımdan yararlanılmıştır (Baucom, Epstein, Sayers ve Sher, 1989; Cramer, 2004; Ellis, 1995; Ellis ve DiGiuseppe, 1993; Epstein ve Eidelson, 1981; Gizir, 2012; Hampel ve Vangelisti, 2008; Kim, 2006; Sar1, 2008; Stackert ve Bursik, 2003). Grup üyelerinin romantik ilişkilerde bağlanma, bağlanma stilleri ve güvenli bağlanmanın özelliklerini tanımalarını sağlamak, kendi bağlanma stillerinin ve bu stilin ilişkilerine olan etkilerinin farkına varmalarını sağlamak için bağlanma kuramından yararlanılmıştır (Ainsworth, Blehar, Waters ve Wall, 2015; Bartholomew, 1990; Bartholomew ve Horowitz, 1991; Bowlby, 1969, 1988; Hazan ve Shaver, 1987; Main, Kaplan ve Cassidy, 1985). Ayrıca, bireylerin romantik ilişkilerdeki cinsiyet farklılıkları (duygu, düşünce ve davranış), bu farklılıkların romantik ilişkilere olan etkilerinin farkına varabilmeleri, romantik ilişkilerdeki cinsiyet farklılıklarını toplumsal cinsiyet rolleri ve kalıp yargılar açısından değerlendirmeleri amacıyla etkinlikler geliştirilmiştir ve uygulanmıştır (Bem ve Lenney, 1976; Cann, Mangum ve Wells, 2001; Coleman ve Ganong, 1992; Frazier ve Esterly, 1990; Hendrick ve Hendrick, 1995; Leaper ve Anderson, 1997; Sakall1-Uğurlu, 2003; Stafford ve Canary, 1991). Bu boyutlar ele al1nırken oturumlarda temel olarak anlatım, soru-cevap, tartışma ve rol oynama gibi yöntemlerden yararlanılmıştır. Programın amacı, katılımcıların yukarıda ifade edilen boyutlarda bilgi, beceri ve farkındalıklarını arttırarak romantik ilişkiden aldıkları doyumun artmasına yardımcı olmaktır. Psikoeğitim programı 8 hafta boyunca deney grubundaki katılımcılarla bir araya gelinerek, haftada 1 kez ve 90 dakika şeklinde uygulanmıştır. Bu süreçte kontrol grubundaki katılımcılara herhangi bir işlem yapılmamıştır. Deney ve kontrol gruplarının İlişki Doyumu Ölçeği ön test ölçümü psikoeğitim oturumları başlamadan önce yapılmıştır, son test ölçümü ise son oturumun ardından bir hafta sonra yapılmıştır.

RİBPP'nin etkinliğini sınamak, programın katılımcılar üzerindeki müdahale sonrası etkilerini izlemek ve söz konusu psikoeğitim programına ilişkin katılımcıların görüşlerini almak amaciyla, programın uygulanmasından sonra deney grubundaki katılımcılarla odak grup görüşmesi gerçekleştirilmiştir. Bu amaçla araştırmacılar, araştırmanın amacından yola çıkarak yarı yapılandırılmış odak grup görüşme formu hazırlamışlardır. $\mathrm{Bu}$ odak grup görüşmesinde deney grubunda yer alan 9 katılımcı ile bu araştırmanın ikinci yazarı görüşmüştür. Odak grup görüşmesi psikoeğitim programının deney grubuna uygulanmasından 3 ay sonra gerçekleştirilmiştir. Görüşme sırasında söylenenler, katılım- 
cıların izni alınarak, kayıt cihazı kullanılarak kaydedilmişsir. Görüşme 40 dakika sürmüştür. Görüşmeyi yapan araştırmacı daha önceden hazırlanmış olan soruları sırası ile katılımcılara sormuştur. Katılımcıların odak grup görüşmesinde söyledikleri deşifre edilerek yazılı metne dönüştürülmüştür.

\section{Verilerin Analizi}

Araştırmanın hipotezini test etmek için karma desen iki yönlü ANOVA testi kullanılmıştır. İzleme ve psikoeğitim programın etkinliğini değerlendirmek amacıyla gerçekleştirilen odak grup görüşmesi sırasında katılımcıların izniyle kayda alınan 40 dakikalık ses dosyası deşifre edilmiş ve sonucunda 11 sayfalık veri elde edilmiştir. Veriler nitel veri analizi yöntemlerinden içerik analizi yoluyla analiz edilmiştir. İçerik analizinin ilk aşamasında toplanan veriler odak grup görüşmesini gerçekleştiren bu araştırmanın ikinci yazarı tarafından kodlanmış ve bu kodlara göre sınıflandırılmıştır. Daha sonra diğer iki yazar bu kodları incelemiştir. Tematik kodlama yoluyla ortaya çıkan kodları genel düzeyde açıklayabilecek temaların oluşturulması için kodlamalar bir araya getirilmiştir. Tematik kodlama sürecinden sonra veriler kod ve temalara göre düzenlenmiş ve tanımlanmıştır. Elde edilen benzer kodların belirli ortak temalar altında toplanması sürecinde üç yazar aralarında görüş alışverişinde bulunmuştur. Bu yolla analiz sürecinde üç yazarın aynı veriye ilişkin görüşleri alınarak tek araştırmacı yanlılığı giderilmeye ve araştırmada verilerin geçerlik ve güvenirliği sağlanmaya çalışılmıştır. Yapılan kodlamalar karşılaştırılmış, kodlama ve analiz sürecinde üç yazarın da görüşleri alınmış bu sayede bulguların iç güvenirliği sağlanmaya çalışılmıştır. Ayrıca içerik analizi sürecinde iç geçerliği sağlamak için kodlamalar sırasında bir yazar tarafından yapılan kodlamaların veriye uygunluğu, elde edilen bulguların bir bütün olarak kendi içinde anlamlı ve tutarlı olup olmadığı diğer iki yazar tarafından incelenmiş ve doğrudan alıntılara yer verilmiştir. RIBPP katılımcılarından alıntı yapılırken katılımcılar " $\mathrm{K} 1$ " şeklinde kodlanmış ve katılımcılara verilen kodlar yapılan alıntıların sonuna eklenmiştir. Son olarak elde edilen bulgular araştırmanın amaçları doğrultusunda yorumlanmıştır.

\section{BULGULAR}

"Katılımcıların ilişki doyumu puanlarına ilişkin tekrarlı (ön test-son test) ölçümlerinde gözlenen değişim, deney ve kontrol grupları arasında anlamlı bir fark göstermektedir." hipotezini test etmek için karma desen iki yönlü ANOVA testi kullanılmıştır. Analiz yapılmadan önce parametrik testlerin varsayımlarının karşılanıp karşılanmadığı 
incelenmiştir. Bu amaçla öncelikle sürekli verilerin normal dağılıp dağılmadığı incelenmiştir. Normallik testi için yapılan Shapiro-Wilks istatistiğinin anlamlı olmadığ dolay1sıla normalliğin sağlandığı görülmüştür. Varyansların homojenliğine Levene $F$ testi ile bakılmış ve varyansların homojenliği koşulunun tüm gruplarda karşılandığı görülmüştür. Ölçüm setlerinin ikili kombinasyonları için grupların kovaryanslarının eşitliği Box’s M Testi ile kontrol edilmiştir. Box's M testi sonuçlarına göre (Box's $M=4.36, F(1,19)$ $=1.28, p>.05$ ) grupların varyans-kovaryans matrislerinin eşit olduğu saptanmıştır. $\mathrm{Bu}$ sonuca dayanarak verilerin karma desen iki yönlü ANOVA testi için uygun olduğu ortaya çıkmıştır. Deney ve kontrol gruplarında yer alan öğrencilerin İlişki İstikrarı Ölçeği’nin İlişki Doyumu alt ölçeğinden aldıkları ön test-son test ortalama puan ve standart sapma değerleri Tablo 3’te verilmiştir.

Tablo 3. Deney ve Kontrol Gruplarına İlişkin İlişki Doyumu Ölçeği Ortalama ve Standart Sapma Değerleri

\begin{tabular}{|c|c|c|c|c|c|c|}
\hline & \multicolumn{6}{|c|}{ Ölçüim } \\
\hline & \multicolumn{3}{|c|}{ Ön test } & \multicolumn{3}{|c|}{ Son test } \\
\hline & $N$ & Ort. & $S S$ & $N$ & Ort & $S S$ \\
\hline Deney Grubu & 12 & 41.92 & 2.27 & 9 & 49.00 & 5.43 \\
\hline Kontrol Grubu & 12 & 44.17 & 6.75 & 12 & 39.00 & 8.45 \\
\hline
\end{tabular}

Psikoeğitim programı uygulaması başladığında deney grubu yukarıda ifade edildiği gibi 12 üye ile başlamıştır ve ön test ölçümü de 12 kişiyle gerçekleştirilmiştir. Ancak program uygulaması başladıktan sonra deney grubunda bulunan 3 üye kendi istekleriyle araştırmadan ayrılmışlardır. Bundan dolayı deney grubu son test ölçümü kalan 9 üye ile gerçekleştirilmiştir. Tablo 3 'te görüldüğü üzere, RİBPP uygulanan deney grubundaki katılımcıların ilişki doyumu düzeylerinde bir artış, herhangi bir işlem yapılmayan kontrol grubundaki öğrencilerin ilişki doyumu düzeylerinde ise düşüş gözlenmiştir.

$\mathrm{Bu}$ araştırmada RİBPP’nin etkinliği sınanmıştır. Buna göre psikoeğitim programı uygulamasına katılan deney grubundaki öğrencilerde deney öncesine göre deney sonrasında gözlenen söz konusu değişmenin, psikoeğitim programı uygulamasına katılmayan kontrol grubundaki öğrencilerin ilişki doyumu düzeylerine göre anlamlı bir farklılık gösterip göstermediğine ilişkin karma desen iki faktörlü ANOVA sonuçları Tablo 4'te sunulmuştur. 
Tablo 4. Deney ve Kontrol Gruplarının Ön Test-Son Test İlişsi Doyumu Puanlarına İlişkin Karma Desen İki Yönlü (2x2) ANOVA Sonuçları

\begin{tabular}{|c|c|c|c|c|c|c|}
\hline Varyansın Kaynağı & $\begin{array}{c}\text { Kareler } \\
\text { Toplamı } \\
\text { (KT) }\end{array}$ & $\begin{array}{c}\text { Serbestlik } \\
\text { Derecesi } \\
\text { (s.d.) }\end{array}$ & $\begin{array}{c}\text { Ortalama Kareler } \\
\text { Toplamı } \\
(\text { OKT })\end{array}$ & $\boldsymbol{F}$ & $p$ & $\eta^{2}$ \\
\hline \multicolumn{7}{|l|}{ Deneklerarası } \\
\hline Grup (Deney-Kontrol) & 65.00 & 1 & 65.00 & .71 & .40 & .04 \\
\hline Hata & 1724.90 & 19 & 90.78 & & & \\
\hline \multicolumn{7}{|l|}{ Denekleriçi } \\
\hline Ölçüm (Ön test-Son test) & 55.33 & 1 & 55.33 & 4.37 & .04 & .19 \\
\hline Grup*Ölçüm & 443.91 & 1 & 443.91 & 35.06 & .000 & .65 \\
\hline Hata & 240.57 & 19 & 12.66 & & & \\
\hline Toplam & 2529.71 & 41 & & & & \\
\hline
\end{tabular}

Tablo 4 incelendiğinde ilk olarak, gruplar arası deney ve kontrol gruplarının tekrarlı ölçümlerinden elde edilen ilişki doyumu düzeylerine ilişkin toplam puanları arasında anlamlı bir fark olmadığı görülmektedir, $F(1,19)=.71, p>.05$. Buna göre deney ve kontrol gruplarının ilişki doyumu düzeylerine ilişkin toplam puanları arasında anlamlı bir fark olmadığ́ görülmektedir. İkinci olarak, gruplar içi ön-test son-test ilişki doyumu düzeylerine ilişkin puanlar arasında anlamlı bir fark olduğu görülmektedir, $F(1,19)=$ 4.37, $p<.05$. Bir diğer ifadeyle, katılımcıların hangi grupta olduğuna bakmaksızın ön test ve son test ilişki doyumu düzeylerine ilişkin puanları arasında anlamlı fark olduğu görülmektedir. Tablo 4'teki bulgulara göre, deney ve kontrol grubunda yer alan katılımcıların ilişki doyumu düzeylerinin ön test-son test ölçümlerinde deney öncesinden sonrasına anlamlı farklılık gösterdiği yani farklı işlem gruplarında olmak ile tekrarlı ölçümler faktörlerinin ilişki doyumu üzerindeki ortak etkilerinin anlamlı olduğu bulunmuştur, $F(1,19)=35.06, p<.001$. Ayrıca bu araştırmada grup ortalamaları arasındaki farkların büyüklüğünü incelemek amacıyla etki büyüklüğü $\left(\eta^{2}\right)$ hesaplanmıştır. Kısmi eta kare değeri için, $\eta^{2}>.14$ ise bu değer yüksek düzeyde etkiye işaret etmektedir (Cohen, 1988). Buna göre grupların (deney-kontrol) ve tekrarlı ölçümlerin (ön test-son test) ortak etkileşiminin ilişki doyumu puanları üzerinde yüksek bir etkiye $\left(\eta^{2}=.65\right)$ sahip olduğu belirlenmiştir. Bu sonuçlar araştırmanın hipotezinin doğrulandığı anlamına gelmektedir. Buna göre, katılımcıların ilişki doyumu düzeyi puanlarına ilişkin tekrarlı (ön test-son test) ölçümlerinde gözlenen değişim, deney ve kontrol grupları arasında anlamlı bir şekilde fark göstermiştir. Bir diğer ifadeyle, RİBPP'nin, üniversite öğrencilerine romantik ilişkiler konusunda çeşitli konularda bilgi, farkındalık ve beceriler kazandırma konusunda etkili olduğu sonucuna varılmıştır. 
RİBPP'nin etkinliğini sınamak için deney grubunda yer alan katılımcılar üzerindeki müdahale sonrası etkilerini izlemek amacıyla ikinci araştırmacı tarafından gerçekleştirilen odak grup görüşmesinden elde edilen veriler içerik analizi ile incelenmiştir. Bu analiz sonucunda; ilişki doyumu, farkındalık, bilgi ve beceri, programın anlamı ve hedefe ulaşma temalarına erişilmiştir. İlişki doyumuyla ilgili olarak katılımcılar; eğitim sırasında ve sonrasında romantik ilişkilerle ilgili farkındalıklar kazandıklarını, partnerleriyle iletişimlerinde ben dilini kullanmaya özen göstererek iletişim stratejilerini değiştirdiklerini, partnerlerinin beklentileriyle ilgilendiklerini ve bu beklentileri önemsediklerini ifade etmişlerdir. Katılımcıların, ilişki doyumu teması altında ifade ettikleri görüşlere örnek olabilecek alıntılar aşağıda yer almaktadır.

Bir sorun olduğu zaman iki taraflı sorun oluyor ama kendimle ilgili iletişimi arttırmaya çalıştım. Birebir iletişimi, ben dilini kullanmaya çalıştım bunlar fayda sağladı ilişki doyumum için. (K1)

İki tarafin ilişki beklentisinin birbirinden farklı olduğunu gördüm. Bunu bilmek biraz daha anlayış geliştirmemi sağladı. Sorun çözmedi ama soruna bakış açımı değiştirdi. (K4)

Biz erkek arkadaşımla sorunlarımızı çok konuşmuyorduk, üstünü kapatıyorduk daha çok. Bu çalışma sonrasında ben sorunlarımı dile getirmeye başladım. Artık konuşunca ilişkimizin olgunlaştı̆̆ını düşünüyorum. (K6)

Farkındalık temasında katılımcılar; psikoeğitim programıla ilişkileri içerisinde kendilerini ifade etmekte güçlük yaşadıklarını, aslında hiçbir romantik ilişkinin mükemmel olmadığını, ilişki içerisinde işlevsel olmayan bazı tutumlara sahip olduklarını ve iletişimle her şeyi çözebileceklerini fark ettiklerini dile getirmişlerdir. Katılımcıların, farkındalık teması altında ifade ettikleri görüşlere örnek olabilecek alıntılar aşağıda yer almaktadır.

Ben aslında burada kendimi ifade edemediğimi fark ettim. Doğru düzgün ifade ettiğimde problemin daha çabuk çözüldüğ̈̈nü fark ettim ve o yönde ilerlemeye başladım. (K2)

Güven problemi yaşıyordum, sürekli tereddüt halindeydim ama bu gerçekten benim için işime yaramıyormuş. Biraz daha onun söylediklerine gerçekten doğru söylüyor diye yaklaşabileceğimi, ona inanmayı tercih edebileceğimi fark ettim. (K3)

Herkesin romantik ilişkisinde sıkıntıları varmış. Kimsenin ilişkisi mükemmel değilmiş, onu fark ettim. (K5) 
Ben kız arkadaşımı dinlemediğimi ve haklı çıkmaya çalıştığımı fark ettim. Haklı çıkmak için karşı tarafi yıpratmak, kırmak, incitmek hiç umurumda olmuyordu mesela. Bunun hiçbir işlevi olmadığını fark ettim. (K7)

Bilgi ve beceri temasıyla ilişkili olarak katılımcılar; psikoeğitim programı ile birlikte romantik ilişkilerde bağlanma ve romantik ilişkinin evreleri ile ilgili bilgi edindiklerini ve romantik ilişkide iletişime ilişkin yeni beceriler kazandıklarını belirtmişlerdir. Katılımcıların, bilgi ve beceri teması altında ifade ettikleri görüşlere örnek olabilecek alıntılar aşağıda yer almaktadır.

İlişkide yaşadığımız her şeyin bir adı varmış, bir haritamız varmış. Kör uçuyormuşuz biz. Bu ĕgitimle birlikte artık nereden nasıl gittiğimi hangi noktada olduğumu ve burada neler olabileceğini biliyorum. (K4)

Illetişimde 4 nokta vardı, gizil alan azaltılıp açık alan arttırılırsa azaltılırsa ilişkinin daha şeffaf ve açık olacă̆ını bunun için kendini açmanın ve geribildirim vermenin gerektiğini ögrendim. (K8)

Bağlanma tarzımın ilişkilerimi etkilediğini biliyordum ama hem benim bağlanma tarzımın hem de erkek arkadaşımın karşılıklı olarak birbirini nasıl etkilediğini gördüm. (K9)

Katılımcılar programın anlamı temasında, psikoeğitim programına katılmış olmanın, ilişkiyi daha ileriye götürmek, ilişki doyumunu arttırmak, ilişki için çabalamak ve farkındalık kazanmak anlamına geldiğini vurgulamışlardır. Katılımcıların, programın anlamı teması altında ifade ettikleri görüşlere örnek olabilecek alıntılar aşağıda yer almaktadır.

Benim için anlamı ilişkiyi daha ileriye götürmek, istediğim gibi bir ilişki için kendimi değiştirmeye çalıştı̆̆ım, bunun için uğraştı̆̆ım anlamına geliyor. (K1)

İlişki için çabalamak anlamı var benim için. (K3)

Ben eğitime başladığım dönemde biz ilişkide güç savaşı evresindeydik, baya çatışmalıydl. Ben o çatışmaları atlatmak için, ilişkiyi ileriye götürmeye yönelik bir beklentiydi benimkisi. Geminin firtınalı denizi geçmesi gibi bu dönemi geçirip ilişkiyi kurtarabilir miyiz diye bir düşünmüştüm. (K7)

Benim için yolunda gitmeyen bir şeyleri değiştirmek için bir adım atmak anlamına geliyordu. (K8) 
Son olarak tüm katılımcılar, bu psikoeğitim yaşantısının başında belirledikleri kişisel amaçlara \%40 ile \%90 arasında ulaştıklarını ifade etmişlerdir. Elde edilen bu nitel veriler, RİBPP'nin, üniversite öğrencilerine romantik ilişkiler konusunda bilgi, farkındalık ve beceriler kazandırma konusunda anlamlı bir etkisinin olduğunu ortaya koymuştur.

\section{TARTIŞMA}

Bu araştırmada, genç yetişkin bireylere yönelik geliştirilen RİBPP'nin etkinliği s1nanmıştır. Elde edilen bulgular, RİBPP deney grubundaki katılımcıların, kontrol grubunda olup bu eğitimi almayan katılımcılara göre ilişki doyumu düzeylerinde anlamlı bir artış olduğunu göstermiştir. RİBPP'nin katılımcıların ilişki doyumunu attırdığına ilişkin elde edilen bu bulgu, yurtdışı alan yazında yer alan birçok araştırmanın bulgusuyla paralellik göstermektedir (Antle ve ark., 2011; Carson ve ark., 2004; Futris ve ark., 2013; Griffin ve Apostal, 1993; Larson ve ark., 2007; Ledermann ve ark., 2007; Long ve ark., 1999; Parish, 1992; Worthington ve ark., 1997). Ayrıca bu bulgu, ilişki becerilerini arttırmaya yönelik yurt içi alan yazında yapılmış önceki araştırmaların sonuçlarıyla da paralellik göstermektedir (Duran ve Hamamc1, 2010; Haskan-Avc1, 2013; Yalçın ve Ersever, 2015; Yalçıntaş-Sezgin, 2015; Y1lmaz ve Kalkan, 2010).

RİBPP'nin deney grubunda yer alan katılımcılarla yapılan odak grup görüşmesinin sonuçları; bu psikoeğitim sürecinin ilişki doyumu, farkındalık, bilgi ve beceri, programın anlamı ve hedefe ulaşma boyutlarında katılımııların sağlıklı romantik ilişki geliştirmelerini destekler nitelikte olduğunu ve bu olumlu gelişimin psikoeğitim programı sonrasında da devam ettiğini göstermiştir. $\mathrm{Bu}$ bulgular etkinliği sınanan psikoeğitim programının amacını destekleyen bulgulardır. Yurt içi ve yurt dışı alan yazında psikoeğitim programları sonrasında yapılan izleme çalışmalarının birçoğunda elde edilen nicel bulgular, katılımcıların ilişki doyumlarındaki yükselmenin psikoeğitim programı sonrasında da devam ettiğini göstermiştir (Carson ve ark., 2004; Duran ve Hamamc1, 2010; Haskan-Avc1, 2013; Long ve ark., 1999; Worthington ve ark., 1997). Bu araştırmada elde edilen bulgular, alan yazındaki araştırmaların sonuçlarıyla paralellik göstermektedir.

Katılımcıların odak grup görüşmesinde sağlıklı ilişki konusunda olumlu gelişim kaydettiklerini ifade ettikleri boyutlardan biri iletişimdir. Troy ve Lewis-Smith (2006), bireylerin romantik ilişkilerde sıklıkla problem yaşadıkları alanlardan birinin iletişim olduğunu ifade etmiştir. Bununla birlikte yapıcı iletişim tarzlarına sahip olmayan part- 
nerlerin ilişkilerinden aldıkları doyumun da düşeceği belirtilmektedir (Stanley, Markman ve Whitton, 2002). Katılımcılar odak grup görüşmesinde iletişim konusunda yeni beceriler kazandıklarını, partnerleriyle iletişimlerinde ben dilini kullanmaya özen göstererek iletişim stratejilerini değiştirdiklerini ve ilişkide yaşadıkları problemleri iletişimle çözebileceklerini fark ettiklerini ifade etmişlerdir. Bu bulgular bu araştırmada etkinliği sınanan psikoeğitim programının amacını destekleyen bulgulardır. Alan yazında yapılan bir araştırmada, genç yetişkinlerin ilişki geliştirme programlarında en faydalı buldukları boyutlardan birinin iletişim becerileri olduğu belirlenmiştir (Valiente, Belanger ve Estrada, 2002). Ayrıca yurt içi alan yazında yapılan bir araştırmada ilişki geliştirme programına katılan bireyler romantik ilişkilerinde yaşadıkları çatışmaları iletişim becerilerini kullanarak çözmeye çalıştıklarını, iletişim örüntüleriyle ilgili çeşitli farkındalıklar kazandıklarını, çatışmalar sırasında kullandıkları işlevsel olmayan iletişim davranışlarını fark ettiklerini ifade etmişlerdir (Yalçın ve Ersever, 2015). İfade edilen bu bulgular, bu araştırmada odak grup görüşmesiyle elde edilen bulgularla paralellik göstermektedir.

Üniversite çağındaki genç yetişkinlerin sağlıklı romantik ilişkilerle ilgili farkındalıklarını arttırmak RİBPP'nin amaçlarından biridir. Psikoeğitim programı sonrası etkileri izlemek amacıyla yapılan odak grup görüşmesinde katılımcılar, romantik ilişkide kendilerini ifade etmekte güçlük yaşadıklarını, hiçbir romantik ilişkinin mükemmel olmadığını ve ilişki içerisinde işlevsel olmayan bazı tutumlara sahip olduklarını fark etmişlerdir. $\mathrm{Bu}$ açıdan elde edilen bu bulgular etkinliği sınanan psikoeğitim programının amaçlarından birinin gerçekleştiğinin işaretidir. Haskan-Avcı (2013) tarafından yapılan araştırmada, psikoeğitim programına katılan bireylerin iletişim engelleri, etkili iletişim yöntemleri, çatışmalar sırasında nasıl iletişim kurmaları gerektiği ile ilgili çeşitli farkındalıklar kazandığına ilişkin nitel bulgulara ulaşılmıştır. Benzer şekilde romantik ilişki yaşayan çiftlerle yapılan empati eğitim programı çalışmasında, bireylerin kendileri ve ilişkileriyle ilgili farkındalıklarının arttığı saptanmıştır (Angera ve Long, 2006).

$\mathrm{Bu}$ araştırmanın bazı sınırlılıkları da bulunmaktadır. Psikoeğitim programında ele alınan boyutlardan biri cinsiyet farklılıklarıdır. Ancak deney ve kontrol gruplarının demografik bilgilerine bakıldığında her iki gruptaki erkek üye sayısının oldukça az olduğu görülmektedir. Bu durumun araştırmadan elde edilen bulguların cinsiyet açısından değerlendirmesinin önünde önemli bir engel olduğu söylenebilir. Bundan dolayı bundan sonra bu psikoeğitim programı kullanılarak yapılacak yeni araştırmalarda cinsiyet açısından kadın erkek dağılımının dengeli olduğu gruplarla çalışma yapılmasının progra- 
mın etkinliğini test etmek için yararlı olabileceği düşünülmektedir. Alan yazında bazı araştırmacılar, yarı deneysel araştırmalarda kullanılan psikolojik danışma müdahalelerinin etkilerinin çoğunun belirli olmayan faktörlerden kaynaklandığını iddia etmektedir (Frank, Demichele ve Watchel, 1997; Wampold ve Imel, 2015). Bu konuda araştırma deseninde yapılacak çeşitli düzenlemelerle elde edilen bulguların müdahalenin kendisinden mi yoksa plasebo etkisinden mi olduğunu daha net belirlemek mümkün olabilir. Bunun yollarından biri plasebo kontrol grubu kullanılmasıdır (Heppner ve ark., 1999). $\mathrm{Bu}$ araştırmada kontrol grubuna herhangi bir işlem uygulanmamıştır ve plasebo kontrol grubu kullanılmamıştır. Bundan dolayı bundan sonra RİBPP kullanılarak yapılacak yeni araştırmalarda araştırma desenine plasebo kontrol grubu eklenebilir. Bu sayede RİBPP'in etkinliğine ilişkin bulguları, katılımcıların beklentileri, dikkati ya da diğer kaynağı belli olmayan etkilerden ayırmak, plasebo etkisini kontrol etmek mümkün olabilir. $\mathrm{Bu}$ araştırmanın çalışma grubu, Akdeniz bölgesinde bulunan bir üniversitenin psikolojik danışma ve rehberlik lisans programının 1, 2 ve 3. sınıflarında okuyan öğrencilerden oluşmuştur. Çalışma grubundaki katılımcıların psikolojik danışma ve rehberlik lisans programında okuyor olmaları, okudukları lisans programında aldıkları eğitimin yapısı gereği, bu katılımcılara böyle bir psikoeğitim çalışması için bir hazırbulunuşluk sağlamış olabilir. Bundan dolayı bundan sonra bu psikoeğitim programı kullanılarak yapılacak araştırmalarda farklı lisans programlarından oluşturulacak çalışma gruplarıyla çalıŞılmasının programın etkinliğine ilişkin daha zengin kanıt sağlayabileceği düşünülmektedir. Ayrıca bu araştırmadaki çalışma grubu üniversite öğrencilerinden oluşturulmuştur. Bu çalışmanın farklı sosyo-ekonomik niteliklere sahip farklı genç yetişkin gruplarıyla yapılmasının programın genç yetişkinlik çağındaki bireylere genellenebilmesi için önemli olduğuna inanılmaktadır.

Yurt dışı ve yurt içi alan yazın incelendiğinde, olumlu iletişim özellikleri (etkin dinleme, empati gibi; Meeks, Hendrick ve Hendrick, 1998), algilanan empati (Davis ve Oathout, 1987), aşk tutumları (Hendrick, Hendrick ve Adler, 1988), kendini açma (Millar ve Millar, 1988), ilişkisel yeterlik (Canary ve Spitzberg, 1989), çatışma stratejileri (Canary ve Cupach, 1988) ve problem çözme becerileri (Güven ve Sevim, 2007) gibi değişkenlerin bireylerin romantik ilişkiden aldıkları doyumla ilişkili olduğu belirlenmiştir. Ancak bu araştırmada bu faktörlerin olası karıştırıcı etkilerine ilişkin herhangi bir önlem alınmamış ve bu faktörler kontrol edilmeye çalışılmamıştır. Bundan sonra yapılacak araştırmalarda ilgili alan yazındaki araştırma bulguları ışığında ilişki doyumunu et- 
kileyebilecek olası karıştıııcı değişkenlerin kontrol edilerek araştırmaların yürütülmesinin psikoeğitim programının etkinliğine ilişkin elde edilecek sonuçların gücünü arttıracağı düşünülmektedir. Kontrol edilmeyen değişkenlerle birlikte, bu araştırmada bazı değişkenler de kontrol edilmiştir. Farklı psikopatolojilere sahip bireyler için grupla psikolojik danışma uygulamalarının iyileştirici olmadığı ve bu bireylerin bu tür çalışmalardan yararlanma olasılığının düşük olduğu vurgulanmaktadır (Chen ve Rybak, 2004; Yalom, 1995). Bundan dolayı, araştırmanın çalışma grubu oluşturulurken hem grup sürecinin olumsuz etkilenmemesi hem de araştırmaya dahil edilecek bireylerin iyilik hallerinin zarar görmemesi için katılımcıların herhangi bir patolojiye sahip olup olmadıkları KSE genel semptom puanı incelenerek kontrol edilmiştir. Bir başka açıdan, romantik ilişkide fiziksel şiddet yaşantısı olan bireylerin romantik ilişki becerilerine ilişkin programlardan ziyade bu bireyler için hazırlanan özel programlara katılmalarının daha uygun olduğu vurgulanmaktadır (Markman ve ark., 2003; Monarch ve ark., 2002). Bu araştırmada da katılımcıların romantik ilişkideki fiziksel şiddet yaşantıları (partnerinin fiziksel şiddetine maruz kalma ve partnerine fiziksel şiddet uygulama) olup olmadığ Kişisel Bilgi Fromu'na verdikleri bilgiler incelenerek kontrol edilmiş ve fiziksel şiddet yaşantısı olan kişiler araştırmaya dahil edilmemiştir. Ayrıca bu araştırmada kontrol edilen faktörlerden biri de katılımcıların ilişki doyumu düzeyleridir. RİBPP, ilişki doyumu düzeyi ortalama olan bireylerin becerilerini arttırmak ve bu yolla bireylerin ilişki doyumu düzeylerini yükseltmek için tasarlanmıştır, bundan dolayı katılımcıların İiÖ ilişski doyumu alt boyutundan aldıkları puanlar incelenmiş ve sadece ortalama ile ortalamanın 1 standart sapma altında ve ortalama ile ortalamanın 1 standart sapma üstündeki aralıkta bulunan katılımcılar araştırmaya dahil edilmiştir. Böylelikle iç geçerlik için tehdit olabilecek regresyon önlenmeye çalışılııştır (Heppner ve ark., 1999). Katılımcıların belirlenmesinde kullanılan bu içleme ve dışlama kriterleri yoluyla bazı karıştırıcı değişkenlerin kontrol edilmesinin RİBPP'in etkinliğine ilişkin elde edilen ampirik bulguların gücünü arttırdığı düşünülmektedir.

$\mathrm{Bu}$ araştırmada psikoeğitim programının sadece katılımcıların ilişki doyumu üzerindeki etkisi incelenmiştir. Ancak programın içeriğine (bağlanma, inançlar, cinsiyet farkl1lıkları, bağlanma, iletişim gibi) bakıldığında psikoeğitim programının katılımcılara romantik ilişkilerin farklı boyutlarına ilişkin bilgi, beceri veya farkındalıklar kazandırmayı hedeflediği görülmektedir. Ayrıca elde edilen nitel bulgular da psikoeğitim programının katılımcıların ilişki doyumlarının yanında onları farklı alanlarda desteklediğini göster- 
miştir. Bu çerçevede bundan sonra yapılacak araştırmalarda psikoeğitim programının ilişki doyumunun yanı sıra romantik ilişkilerle ilgili diğer değişkenler üzerindeki etkileri de incelenebilir.

\section{Kaynakça}

Acker, M. ve Davis, M. H. (1992). Intimacy, passion and commitment in adult romantic relationships: A test of the triangular theory of love. Journal of Social and Personal Relationships, 9(1), 21-50.

Adler-Baeder, F., Kerpelman, J. L., Schramm, D. G., Higginbotham, B. ve Paulk. A. (2007). The impact of relationship education on adolescents of diverse backgrounds. Family Relations, 56, 291-303.

Ainsworth, M. D. S., Blehar, M. C., Waters, E. ve Wall, S. N. (2015). Patterns of attachment: A psychological study of the strange situation. New York, NY: Psychology Press.

Angera, J. J. ve Long, E. C. (2006). Qualitative and quantitative evaluations of an empathy training program for couples in marriage and romantic relationships. Journal of Couple \& Relationship Therapy, 5(1), 1-26.

Antle, B. F., Sullivan, D. J., Dryden, A., Karam, E. A. ve Barbee, A. P. (2011). Healthy relationship education for dating violence prevention among high-risk youth. Children and Youth Services Review, 33(1), 173-179.

Aron, A. ve Westbay, L. (1996). Dimensions of the prototype of love. Journal of Personality and Social Psychology, 70(3), 535-551.

Arnett, J. J. (2007). Socialization in emerging adulthood: From the family to the wider world, from socialization to self-socialization. J. E. Grusec ve P. D. Hastings (Ed.), Handbook of socialization: Theory and research içinde (ss. 208-231). New York, NY: Guilford Press.

Bader, E. ve Pearson, P. (1983). The developmental stages of couplehood. Transactional Analysis Journal, 13(1), 28-32.

Bagarozzi, D. A., Bagarozzi, J. I., Anderson, S. A. ve Pollane, L. (1984). Premarital education and training sequence (PETS): A 3-year follow-up of an experimental study. Journal of Counseling \& Development, 63(2), 91-100.

Bartholomew, K. (1990). Avoidance of intimacy: An attachment perspective. Journal of Social and Personal Relationships, 7(2), 147-178.

Bartholomew, K. ve Horowitz, L. M. (1991). Attachment styles among young adults: A test of a fourcategory model. Journal of Personality and Social Psychology, 61(2), 226- 244.

Baucom, D. H., Epstein, N., Sayers, S. ve Sher, G. (1989). The role of cognition in marital relationships: Definitional, methodological and conceptual issues. Journal of Consulting and Clinical Psychology, $57,31-38$

Bem, S. L. ve Lenney, E. (1976). Sex typing and the avoidance of cross-sex behavior. Journal of Personality and Social Psychology, 33(1), 48-54.

Bowlby, J. (1969). Attachment and loss: Volume I Attachment (2. bask1). New York: Basic Books Inc.

Bowlby, J. (1988). A secure base: Parent-child attachment and healthy human development. New York: Basic Books Inc.

Braithwaite, S. R., Delevi, R. ve Fincham, F. D. (2010). Romantic relationships and the physical and mental health of college students. Personal Relationships, 17(1), 1-12.

Büyükşahin, A., Hasta, D. ve Hovardaoğlu, İ. S. (2005). İlişki İstikrarı Ölçeği: Geçerlik ve güvenirlik çalışması. Türk Psikoloji Yazıları, 8(16), 25-37. 
Büyükşahin, A. ve Taluy, N. (2008). İlişki İstikrarı Ölçeği'nin gözden geçirme çalışması. Yayımlanmamış araştırma raporu.

Campbell, S. (1980). The couple's journey: Intimacy as a path to wholeness. San Luis Obispo, CA: Impact Publishers.

Canary, D. J. ve Cupach, W. R. (1988). Relational and episodic characteristics associated with conflict tactics. Journal of Social and Personal Relationships, 5(3), 305-325.

Canary, D. J. ve Spitzberg, B. H. (1989). A model of the perceived competence of conflict strategies. Human Communication Research, 15(4), 630-649.

Cann, A., Mangum, J. L. ve Wells, M. (2001). Distress in response to relationship infidelity: The roles of gender and attitudes about relationships. Journal of Sex Research, 38(3), 185-190.

Carson, J. W., Carson, K. M., Gil, K. M. ve Baucom, D. H. (2004). Mindfulness-based relationship enhancement. Behavior Therapy, 35, 471-494.

Chen, M. ve Rybak, C. J. (2004). Group leadership skills: Interpersonal process in group counseling and therapy. Belmont, CA: Brooks-Cole.

Cohen, J. W. (1988). Statistical power analysis for the behavioral sciences (2. bask1). Hillsdale, NJ: Lawrence Erlbaum Associates.

Coleman, M. ve Ganong, L. (1992). Gender differences in expectations of self and future partner. Journal of Family Issues, 33, 55-61.

Collins, A. ve van Dulmen, M. (2006). Friendships and romance in early adulthood: Assessing distinctiveness is close relationships. J. J. Arnett ve J. L. Tanner (Ed.), Emerging adults in America: Coming of age in the 21st century içinde (ss. 219-234). Washington, DC: American Psychological Association.

Cornish, P. A. ve Benton, D. (2001). Getting started in healthier relationships: Brief integrated dynamic group counseling in a university counseling setting. Journal for Specialists in Group Work, 26(2), 129-143.

Cramer, D. (2004). Effect of the destructive disagreement belief on relationship satisfaction with a romantic partner or closest friend. Psychology and Psychotherapy: Theory, Research and Practice, 77(1), 121-133.

Davis, M. H. ve Oathout, H. A. (1987). Maintenance of satisfaction in romantic relationships: Empathy and relational competence. Journal of Personality and Social Psychology, 53(2), 397-410.

Derogatis, L. R. (1992). The Brief Symptom Inventory (BSI): Administration, scoring and procedures manual-II. Baltimore: Clinical Psychometric Research Inc..

Derogatis, L. R., Rickels, K. ve Rock, A. F. (1976). The SCL-90 and the MMPI: A step in the validation of a new self-report scale. The British Journal of Psychiatry, 128(3), 280-289.

Duran, Ş. ve Hamamcı, Z. (2010). Evlilik öncesi ilişki geliştirme programının romantik ilişkiler yaşayan üniversite öğrencilerinin iletişim becerileri ve çatışma iletişim tarzları üzerine etkisinin incelenmesi. Sosyal Politika Çalışmaları Dergisi, 6(23), 87-99.

Ellis, A. (1995). Changing Rational Emotive Therapy (RET) Rational Emotive Behaviour Therapy (REBT). Journal of Rational Emotive and Cognitive Behaviour Therapy, 13(2), 85-89.

Ellis, A. ve DiGiuseppe, R. (1993). Are inappropriate or dysfunctional feelings in Rational Emotive Therapy qualitative or quantitative. Cognitive Therapy and Research, 17(5), 471-477.

Epstein, N. ve Eidelson, R. (1981). Unrealistic beliefs of clinical couples: Their relationship to expectations, goals and satisfaction. American Journal of Family Therapy, 9, 13-22.

Erikson, E. H. (1968). Identity: Youth and crisis. New York: Norton.

Erkan, S., Özbay, Y., Cihangir-Çankaya, Z. ve Terzi, Ş. (2012). Üniversite öğrencilerinin yaşadıkları problemler ve psikolojik yardım arama gönüllülükleri. Eğitim ve Bilim Dergisi, 37(164), 94-107. 
Falconi, A. ve Mullet, E. (2003). Cognitive algebra of love through the adult life. The International Journal of Aging and Human Development, 57(3), 275-290.

Fehr, B. A. (1986). Prototype analysis of the concepts of love and commitment. (Yayınlanmamış Doktora Tezi). University of British Columbia, Vancouver.

Fehr, B. (1993). How do I love thee? Let me consult my prototype. S. Duck (Ed.), Understanding relationship processes series, Vol. 1. Individuals in relationships içinde (ss. 87-120). Thousand Oaks, CA, US: Sage Publications, Inc.

Fehr, B. ve Russell, J. A. (1991). The concept of love viewed from a prototype perspective. Journal of Personality and Social Psychology, 60(3), 425-438.

Frank, J. D., Demichele, A. ve Wachtel, P. L. (1997). Persuasion and healing: a comparative study of psychotherapy. Psyccritiques, 42(5), 389-391.

Frazier, P. A. ve Esterly, E. (1990). Correlates of relationship beliefs: Gender, relationship experience and relationship satisfaction. Journal of Social and Personal Relationships, 7(3), 331-352.

Futris, T. G., Sutton T. E. ve Richardson E. W. (2013). An evaluation of the Relationship Smarts Plus Program on adolescents in Georgia. Journal of Human Sciences and Extension. 1(2),1-15.

Gaw, B. A. (1976). The Johari window and a partnership: An approach to teaching interpersonal communication skills. Communication Education, 25(3), 252-255.

Gizir, C. A. (2005). Orta Doğu Teknik Üniversitesi son sınıf öğrencilerinin problemleri üzerine bir çalışma. Mersin Üniversitesi Eğitim Fakültesi Dergisi, 1(2), 196-213.

Gizir, C. A. (2012). İlişki İnançları Ölçeği'nin uyarlanması: Geçerlik ve güvenirlik çalışmaları. Mersin Üniversitesi Ĕ̈itim Fakültesi Dergisi, 8(2), 35-45.

Gottman, J. ve Gottman, J. (2008). Gottman method couple therapy. A. S. Gurman (Ed.), Clinical handbook of couple therapy içinde (4. bask1) (ss. 138-164). New York, NY: Guilford Press.

Griffin Jr, J. M. ve Apostal, R. A. (1993). The influence of relationship enhancement training on differentiation of self. Journal of Marital and Family Therapy, 19(3), 267-272.

Guerney, B. G. (2005). Relationship Enhancement couple/marital/family therapist's manual. (4. bask1). Bethesda: Ideals Inc.

Güven, N. ve Sevim, S. (2007). İlişkilerle ilgili bilişsel çarpıtmalar ve algılanan problem çözme becerilerinin evlilik doyumunu yordama gücü. Türk Psikolojik Danışma ve Rehberlik Dergisi, 3(28), 50-61.

Hampel, A. D. ve Vangelisti, A. L. (2008). Commitment expectations in romantic relationships: Application of a prototype interaction-pattern model. Personal Relationships, 15, 81-102.

Haskan-Avcı, Ö. (2013). Evliliğe hazırlık programının çift ilişkileri ve ilişki istikrarı üzerindeki etkisi. (Yayınlanmamış Doktora Tezi). Hacettepe Üniversitesi Eğitim Bilimleri Enstitüsü, Ankara.

Hazan, C. ve Shaver, P. (1987). Romantic love conceptualized as an attachment process. Journal of Personality and Social Psychology, 52(3), 511-524.

Hendrick, S. S. ve Hendrick, C. (1995). Gender differences and similarities in sex and love. Personal Relationships, 2, 55-65.

Hendrick, S. S., Hendrick, C. ve Adler, N. L. (1988). Romantic relationships: Love, satisfaction, and staying together. Journal of Personality and Social Psychology, 54(6), 980-988.

Heppner, P. P., Wampold, B. E. ve Kivlighan, D. M. Jr. (1999). Research design in counseling (2. bask1). Belmont, CA: Wadsworth.

Hoffman, K. (2012). An Attachment-Based Romantic Relationships Intervention for young adults (Yayınlanmamış Doktora Tezi). California School of Professional Psychology, San Francisco.

Kağıtçıbaşı, Ç. (2008). Günümüzde insan ve insanlar: Sosyal psikolojiye giriş. İstanbul: Evrim Yayınevi. 
Karaırmak, Ö. (2008). Çok kültürlülük, kültürel duyarlılık ve psikolojik danışma. Türk Psikolojik Danışma ve Rehberlik Dergisi, 3(29), 115-129.

Keitner, G. I., Heru A. M. ve Glick I. D. (2010). Clinical manual of couples and family therapy. Washington, DC: American Psychiatric Publishing, Inc.

Kılıç, M. (1995). Üniversite öğrencilerinin ruh sağlı̆̆ını bozan nedenler ve tedavide başvurdukları çözüm yolları. İnönü Üniversitesi Ĕ̈itim Bilimleri Dergisi, 2, 86-93.

Kilmann, P. R., Urbaniak, G. C. ve Parnell, M. M. (2006). Effects of attachment-focused versus relationship skills-focused group interventions for college students with insecure attachment patterns. Attachment \& Human Development, 8(1), 47-62.

Kim, Y. (2006). Cognitive concepts of the self and romantic relationships. Basic and Applied Social Psychology, 28(2), 169-175.

Larson, J. H., Vatter, R. S., Galbraith, R. C., Holman, T. B. ve Stahmann, R. F. (2007). The RELATionship Evaluation (RELATE) with therapist-assisted interpretation: Short-term effects on premarital relationships. Journal of Marital and Family Therapy, 33(3), 364-374.

Leaper, C. ve Anderson, K. J. (1997). Gender development and heterosexual romantic relationships during adolescence. New Directions for Child and Adolescent Development, 78, 85-103.

Ledermann, T., Bodenmann, G. ve Cina, A. (2007). The efficacy of the couples coping enhancement training (CCET) in improving relationship quality. Journal of Social and Clinical Psychology, 26(8), 940-959.

Long, E. C., Angera, J. J., Carter, S. J., Nakamoto, M. ve Kalso, M. (1999). Understanding the one you love: A longitudinal assessment of an empathy training program for couples in romantic relationships. Family Relations, 48, 235-242.

Luft, J. ve Ingham, H. (1961). The johari window. Human Relations Training News, 5(1), 6-7.

Main, M., Kaplan, N. ve Cassidy, J. (1985). Security in infancy, childhood, and adulthood: A move to the level of representation. Monographs of the Society for Research in Child Development, 50(1), 66-104.

Markman, H. J., Stanley, S. M., Blumberg, S. L., Jenkins, N. H. ve Whiteley, C. (2003). 12 hours to a great marriage: A step-by-step guide for making love last. San Francisco: John Wiley \& Sons.

Marston, P. J., Hecht, M. L., Manke, M. L., McDaniel, S. ve Reeder, H. (1998). The subjective experience of intimacy, passion, and commitment in heterosexual loving relationships. Personal Relationships, 5(1), 15-30.

Meeks, B. S., Hendrick, S. S. ve Hendrick, C. (1998). Communication, love and relationship satisfaction. Journal of Social and Personal Relationships, 15(6), 755-773.

Millar, K. U. ve Millar, M. G. (1988). Sex differences in perceived self-and other-disclosure: A case where inequity increases satisfaction. Social Behavior and Personality: An International Journal, 16(1), 59-64.

Monarch, N. D., Hartman, S. G., Whitton, S. W. ve Markman, H. J. (2002). The role of clinicians in the prevention of marital distress and divorce. N. S. Jacobson ve A. S. Gruman (Ed.) Clinical handbook for couple's therapy içinde (3. bask1). New York: Guilford Press.

Naar, R. (1993). Grup psikoterapisine ilk adım (N. H. Şahin, Çev.). İstanbul: İmge Kitapevi Yayınları. (Orijinal çalışma basım tarihi 1986).

Nunnally, E. W., Miller, S. ve Wackman, D. B. (1975). The Minnesota couples communication program. Small Group Behavior, 6(1), 57-71.

Parish, W. E. (1992). A quasi-experimental evaluation of the Premarital Assessment Program for premarital counseling. Australia-New Zealand Journal of Family Therapy, 134, 33-36. 
Parrott, L. ve Parrott, L. (1997). Preparing couples for marriage: The SYMBIS model. Marriage and Family: A Christian Journal, 1, 49-53.

Pronin, E., Lin, D. Y. ve Ross, L. (2002). The bias blind spot: Perceptions of bias in self versus others. Personality and Social Psychology Bulletin, 28(3), 369-381.

Renick, M. J., Blumberg, S. L. ve Markman, H. J. (1992). The Prevention and Relationship Enhancement Program (PREP): An empirically based preventive intervention program for couples. Family Relations, 41, 141-147.

Rusbult, C. E., Martz, J. M. ve Agnew, C. R. (1998). The investment model scale: Measuring commitment level, satisfaction level, quality of alternatives, and investment size. Personal Relationships, 5(4), $357-387$.

Sakall1-Uğurlu, N. (2003). How do romantic relationship satisfaction, gender stereotypes and gender relate to future time orientation in romantic relationships? The Journal of Psychology, 137(3), 294303.

Sarı, T. (2008). Üniversite öğrencilerinin romantik ilişsilerle ilgili akılcı olmayan inançlar, bağlanma boyutları ve ilişki doyumu arasındaki ilişkiler (Yayınlanmamış Doktora Tezi). Hacettepe Üniversitesi Sosyal Bilimler Enstitüsü, Ankara.

Shollenberger, M. A. (2001). Increasing marital adjustment in graduate students and their spouses through relationship enhancement (Yayınlanmamış Doktora Tezi). Virginia Polytechnic Institute and State University, Blacksburg.

South, B. (2007). Combining mandala and the Johari Window: An exercise in self-awareness. Teaching and Learning in Nursing, 2(1), 8-11.

Stackert, R. A. ve Bursik, K. (2003). Why am I unsatisfied? Adult attachment style, gendered irrational relationship beliefs and young adult romantic relationship satisfaction. Personality and Individual Differences, 34, 1419-1429.

Stafford, L. ve Canary, D. J. (1991). Maintenance strategies and romantic relationship type, gender and relational characteristics. Journal of Social and Personal Relationships, 8(2), 217-242.

Stanley, S. M., Markman, H. J. ve Whitton, S. W. (2002). Communication, conflict, and commitment: Insights on the foundations of relationship success from a national survey. Family Process, 41(4), 659-675.

Sternberg, R. J. (1986). A triangular theory of love. Psychological Review, 93(2), 119-135.

Stover, C. L. (2008). Adolescents attitudes towards counseling by demographic group: Before and after a youth relationship education curriculum (Yayınlanmamış Yüksek Lisans Tezi). Graduate Faculty of Auburn University, Alabama.

Şahin, N. H. ve Durak, A. (1994). Kısa Semptom Envanteri: Türk gençleri için uyarlanması. Türk Psikoloji Dergisi, 9(31), 44-56.

Şen, B. (2009). Evlenmek üzere başvuruda bulunan bir grup nişanlı çiftin evlilik ve "Evlilik Öncesi Çift Eğitimi”"ne ilişskin bilgi, görüş ve değerlendirmeleri (Yayınlanmamış Yüksek Lisans Tezi). Hacettepe Üniversitesi Sosyal Bilimler Enstitüsü, Ankara.

Topkaya, N. ve Meydan, B. (2013). Üniversite öğrencilerinin problem yaşadıkları alanlar, yardım kaynakları ve psikolojik yardım alma niyetleri. Trakya Üniversitesi Eğitim Fakültesi Dergisi, 3(1), $25-37$.

Troy, A. B. ve Lewis-Smith, J. (2006). Preliminary findings on a brief self-disclosure intervention with young adult dating couples. Journal of Couple \& Relationship Therapy, 5(2), 57-69.

Valiente, C. E., Belanger, C. J. ve Estrada, A. U. (2002). Helpful and harmful expectations of premarital interventions. Journal of Sex \& Marital Therapy, 28(1), 71-77. 
Vazire, S. ve Mehl, M. R. (2008). Knowing me, knowing you: the accuracy and unique predictive validity of self-ratings and other-ratings of daily behavior. Journal of Personality and Social Psychology, 95(5), 1202-1216.

Wampold, B. E. ve Imel, Z. E. (2015). The great psychotherapy debate: The evidence for what makes psychotherapy work. New York: Routledge.

Weisskirch, R. S. (2017) Abilities in romantic relationships and well-being among emerging adults. Marriage \& Family Review, 53(1), 36-47.

Worthington Jr, E. L., Hight, T. L., Ripley, J. S., Perrone, K. M., Kurusu, T. A. ve Jones, D. R. (1997). Strategic hope-focused relationship-enrichment counseling with individual couples. Journal of Counseling Psychology, 44(4), 381-389.

Yalçın, İ. ve Ersever, O. (2015). İlişki Geliştirme Programının üniversite öğrencilerinin ilişki doyum düzeylerine etkisi. Hacettepe Üniversitesi Eğitim Fakültesi Dergisi, 2(30), 185-201.

Yalçıntaş-Sezgin, E. (2015). Ergen romantik ilişskisinde sağglılı ilişskiler gelişstirme programının kız ergen bireylerin romantik iliş̧ki sürecinde yaşadıkları çatışma eğilimine etkisi (Yayımlanmamış Doktora Tezi). Gazi Üniversitesi Sosyal Bilimler Enstitüsü, Ankara.

Yalom, I. D. (1995). The theory and practice of group pschotherapy (4. bask1). New York: Basic Books. Yazıc1, E. (2003). Türk üniversite gençliği araştırması. Ankara: Gazi Üniversitesi Yayınları.

Y1lmaz, T. ve Kalkan, M. (2010). The effects of a Premarital Relationship Enrichment Program on relationship satisfaction. Educational Sciences: Theory and Practice, 10(3), 1911-1920. 
